\title{
Predation of birds by the Barn Owl (Tyto furcata Temminck, 1827) in four environ- ments in southern Santa Fe province, Argentina
}

\section{Depredación de aves por la Lechuza (Tyto furcata Temminck, 1827) en cuatro ambientes del sur de la provincia de Santa Fe, Argentina}

DOI: $10.53499 /$ sfjeasv1n3-001

Received in: March 1st, 2020.

Accepted in: June 30th, 2020.

\section{Daniel Alejandro Paiz \\ Assistant of 2nd Chair of Biology and Ecology (FCV-UNR)}

Faculty of Veterinary Sciences, National University of Rosario. Ovidio Lagos Boulevard and Route 33, Casilda, Santa Fe, Argentina.

E-mail: paizdaniel@fcv.unr.edu.ar

\section{Pablo Guillermo Rimoldi}

Ph. D. in Veterinary Sciences from the National University of Rosario (Argentina), School of Veterinary Sciences.

Faculty of Agricultural Sciences, National University of Rosario. Villarino Experimental Field, C.C. 14 (S2125ZAA) Zavalla, Santa Fe, Argentina.

Faculty of Veterinary Sciences, National University of Rosario. Ovidio Lagos Boulevard and Route 33, Casilda, Santa Fe, Argentina.

E-mail: primoldi04@gmail.com

\begin{abstract}
In this paper we present the birds that make up the diet of Tyto furcata in four environments in the south of the province of Santa Fe, where previous data were practically nonexistent. From this contribution, 37 individuals corresponding to three Orders and 10 Families could be established as part of the diet of this raptor. The family with the most predated representatives was Thraupidae $(n=19)$ with three genera: Sicalis, Zonotrichia and Sporophila. The average body size of the prey was $17 \mathrm{~cm}$. The peri-urban/suburban (AP/S) environment had the greatest diversity of prey consumed. In all environments, the highest abundance occurred in the warm seasons (spring-summer), corresponding to the decrease in micromammal populations. This type of study demonstrates the effectiveness of pellet analysis as a tool to know the existing species in highly anthropized environments.
\end{abstract}

Key words: Tyto furcata, Santa Fe, pellets, predation, birds.

\section{RESUMEN}

En este trabajo se presentan las aves que componen la dieta de Tyto furcata en cuatro ambientes del sur de la provincia de Santa Fe, donde los datos anteriores eran prácticamente inexistentes. A partir de este aporte se pudo establecer que 37 individuos correspondientes a tres órdenes y 10 familias forman parte de la dieta de esta rapaz. La familia con más representantes depredados fue Thraupidae $(n=19)$ con tres géneros: Sicalis, Zonotrichia y Sporophila. El tamaño medio del cuerpo de las presas fue de $17 \mathrm{~cm} . \mathrm{El}$ entorno periurbano/suburbano (PA/S) presentó la mayor diversidad de presas consumidas. En todos los entornos, la mayor abundancia se produjo en las estaciones cálidas (primavera-verano), lo que se corresponde con la disminución de las poblaciones de micromamíferos. Este tipo de estudio demuestra la eficacia del análisis de egagrópilas como herramienta para conocer las especies existentes en ambientes 
altamente antropizados.

Palabras clave: Tyto furcata, Santa Fe, egagrópilas, depredación, aves.

\section{INTRODUCTION}

The study of the diet of raptors can help to better understand the distribution, abundance, behavior and vulnerability of prey species (Fulk 1976, Martí 1987). The order Strigiformes has the largest number of diet studies of these birds worldwide (Bó et al., 2007). In this branch of ecology, trophic studies on raptors are commonly conducted for the family Tytonidae, and the barn owl (Tyto furcata) stands out for being a top predator and being among the species with the highest number of descriptions of feeding habits (González- Calderón 2017).

In Argentina, most of the contributions documenting the diet of Tyto furcata were made in agroecosystems and/or open natural environments in the Pampean region in the province of Buenos Aires (Pardiñas and Cirignoli 2002; González Fischer et al., 2012), in addition to works in the provinces of Misiones, La Pampa and certain regions of northern Patagonia (Chubut and Río Negro), among others (Pardiñas and Cirignoli, 2002). With respect to the south of the province of Santa Fe, little has been known so far, however, in recent years important contributions have been made by the authors of this research (Paiz et al., 2019; Rimoldi, 2020; Rimoldi, 2021a; Rimoldi, 2021b; Rimoldi and Curti, 2021a; Rimoldi and Curti, 2021b).

Most studies describe this bird as an opportunistic raptor that preys mainly on small mammals such as rodents and marsupials (Bellocq 1990; González Acuña et al., 2004; Hercolini 2007; Solaro et al., 2012; d' Hiriart et al., 2017), although other items have been reported in its diet, such as arthropods, lagomorphs, chiroptera, small reptiles, amphibians and birds (Noriega et al., 1993; Ramírez et al. 2000, González Acuña et al., 2004).

With respect to the latter group, there are few studies that work specifically on bird predation. We can mention those carried out by Massoia et al. (1989) "Mammals and birds preyed upon by Tyto alba tuidara in Arroyo Yabebyrí, Candelaria Department, Province of Misiones"; Morici, A. (1990) "Aves depredadas por Tyto alba tuidara en San Miguel, Partido de General Sarmiento, Prov. de Buenos Aires" and Dieguez and Corbella (1997) "Aves depredadas por Tyto alba en Reserva Natural La Felipa, Ucacha, Dto. Juárez Celman, Pcia. de Córdoba" among others.

It is for this reason that the contribution presented in this work is of great value with respect to the consumption of birds by Tyto furcata in an area where the lack of previous work allows us to lay the foundations on this subject. 


\section{MATERIALS AND METHOD}

\subsection{STUDY AREA}

Casilda is a locality of the south of the province of Santa Fe, head of the department Caseros. Located between $33^{\circ} 02^{\prime} 39^{\prime \prime}$ south latitude and $61^{\circ} 10^{\prime} 05^{\prime \prime}$ west longitude, it is bordered on the north by the Carcarañá River, on the south by the Sanford and Fuentes districts, on the west by the Los Molinos district and on the east by the San Lorenzo Department, Pujato district and Carcarañá district (Fig. 1).

The total area of the Casilda district is 38,400 hectares $(384 \mathrm{~km} 2)$, of which 1,200 hectares correspond to urban area and the remaining 37,200 hectares to rural area, thus becoming the dominant matrix of the landscape.

Figure 1: Detail of the Casilda district, Caseros Department, southern Santa Fe province, Argentina.

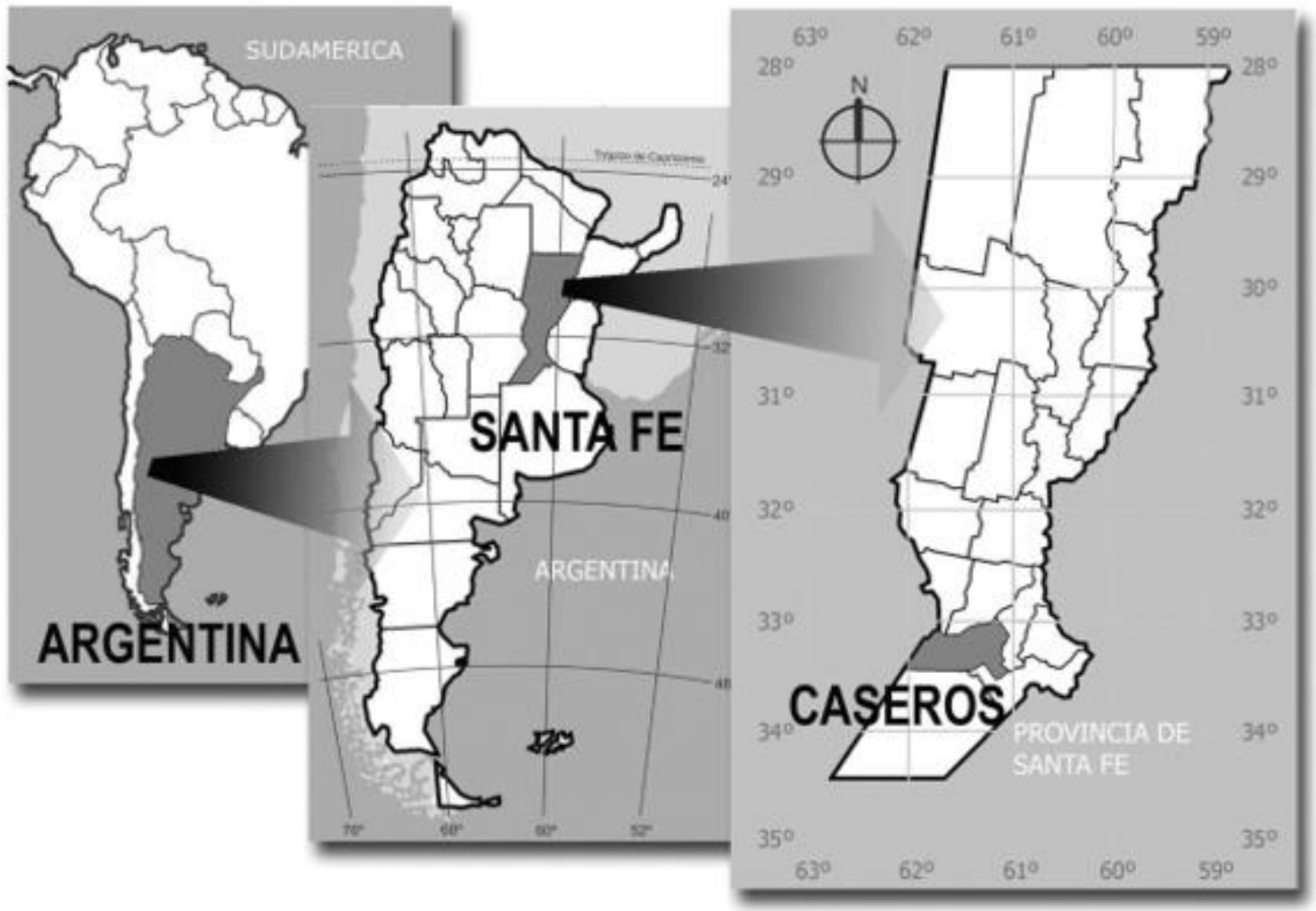




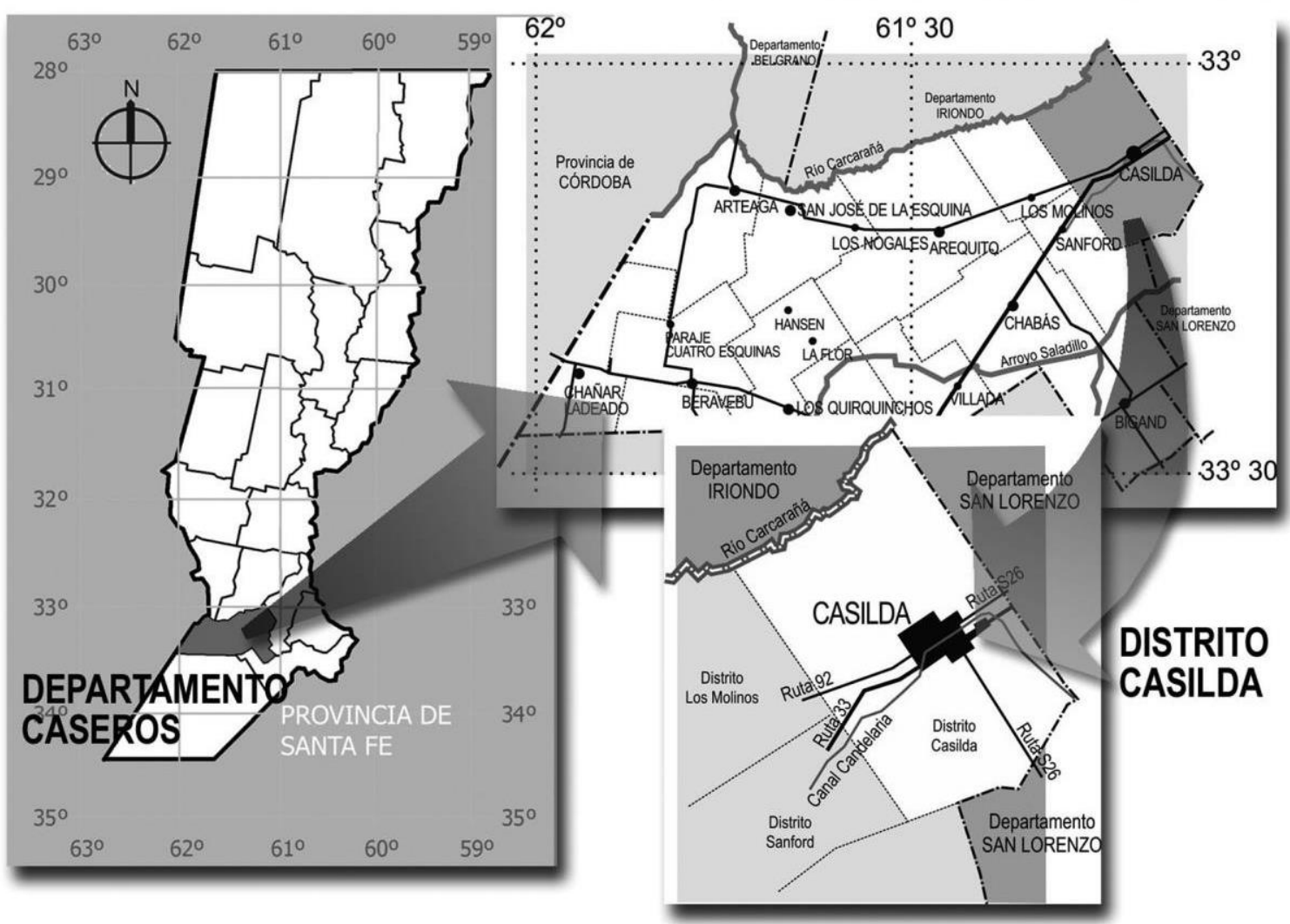

\subsection{CHARACTERIZATION OF THE TERRITORY IN RELATION TO TYPE OF LAND USE}

The type of land use, although there may be certain arbitrariness, responds to some normative criteria and to what has been established by the state (in this case the province) which determines the institutional framework to regulate the administration of the land and the activities that are developed on it. Although the original criterion is a tax classification, its practical consequence in the territory is the type of activity that is exercised in it and the modifications that it implies.

Given that this institutional framework defines the activity, and that anthropic activity is the factor that modifies the support, the type of land use permitted is the factor that imposes new conditions on the territory and, consequently, on the ecosystems.

For this reason, and for the purposes of this work, the criterion of land use type was adopted to characterize the territory determined as the study area and thus establish the sampling sites.

Based on the above, the categories were established as follows:

- Urban environment.

- Suburban or peri-urban environment.

- Rural environment 
1. Anthropized (agricultural-livestock field). Ecosystems whose functioning is based on fuel energy consumption.

2. Non-anthropized or semi-natural (where edaphic or geomorphologic limitations do not allow agriculture or livestock raising, presenting characteristics different from their environment).

Taking into account what has been described for this research, four (04) types of environments belonging to dry land ecosystems within the Casilda district were established:

\begin{tabular}{|c|c|c|c|}
\hline \multicolumn{3}{|c|}{ Established environments for the district of Casilda according to land use } \\
\hline \multirow{2}{*}{ Urban } & $\begin{array}{c}\text { Peri-urban or } \\
\text { suburban }\end{array}$ & Rural \\
\cline { 2 - 4 } & Anthropized & Non-anthropized or natural \\
\hline
\end{tabular}

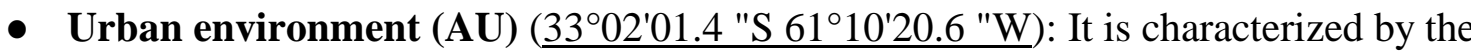
location of the houses occupying the perimeter of the block, leaving spaces occupied by vegetation consisting of grass, trees and shrubs.

- Peri-urban/suburban environment (AP/S) $\left(33^{\circ} 03^{\prime} 21^{\prime \prime} \mathrm{S}, 61^{\circ} 09^{\prime} 11^{\prime \prime} \mathrm{W}\right)$ : Some

structures linked to urban activities that modify the rural agricultural landscape stand out in this environment. The Faculty of Veterinary Sciences of the National University of Rosario is located on National Route 33. Its property covers approximately 240 hectares and was declared a "Natural Protected Area" in 2007 (CD Resolution $N^{\circ}$ 188/07) due to its role as a refuge for wildlife in a purely agricultural area.

- Anthropized Rural Environment (ARA) $\left(33^{\circ} 02^{\prime} 17^{\prime \prime} \mathrm{S}, 61^{\circ} 16^{\prime} 15^{\prime \prime} \mathrm{W}\right)$ : This is a

field characterized by the expansion of wheat-soybean double cropping to the detriment of croplivestock rotations. The conventional tillage system has been replaced by no-tillage using transgenic soybean varieties resistant to the herbicide glyphosate. Ninety-five percent of the surface area is used for this production system.

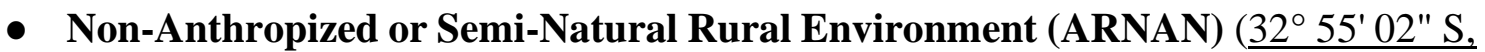

$\left.61^{\circ} 13^{\prime} 27^{\prime \prime} \mathrm{W}\right)$ : The physiognomy of the landscape is characterized, unlike the 
predominant environment (farmland), by notable variations in relatively small spaces. Determined by the course of the Carcarañá River as an axis, an area of variable ecosystemic and regional landscape value is developed.

\subsection{DATA COLLECTION AND ANALYSIS}

Pellets were collected from perches occupied by different specimens of Tyto furcata in the different sampling points previously established, between 2018 and 2020. In all cases, the total was collected leaving the perch clean.

The pellets were placed in labeled paper bags (with the name of the environment surveyed, coordinates, date and quantity) and then in hermetically sealed polyethylene bags, respecting all Biosafety measures (use of latex gloves and a mask during collection) until the material was dried in the laboratory with an oven at $70^{\circ} \mathrm{C}$ for 48 hours (Muñoz-Pedreros and Yañez, 2004). Each pellet was processed, using dissection instruments to extract the skulls of the different birds. The captured prey were compared with samples identified in osteological collections and specialized literature to obtain the specific richness (Fig. 2).

Figure 2. A) Tyto furcata specimen. B) Pellet samples. C) Recognition of birds. D) Laboratory work.
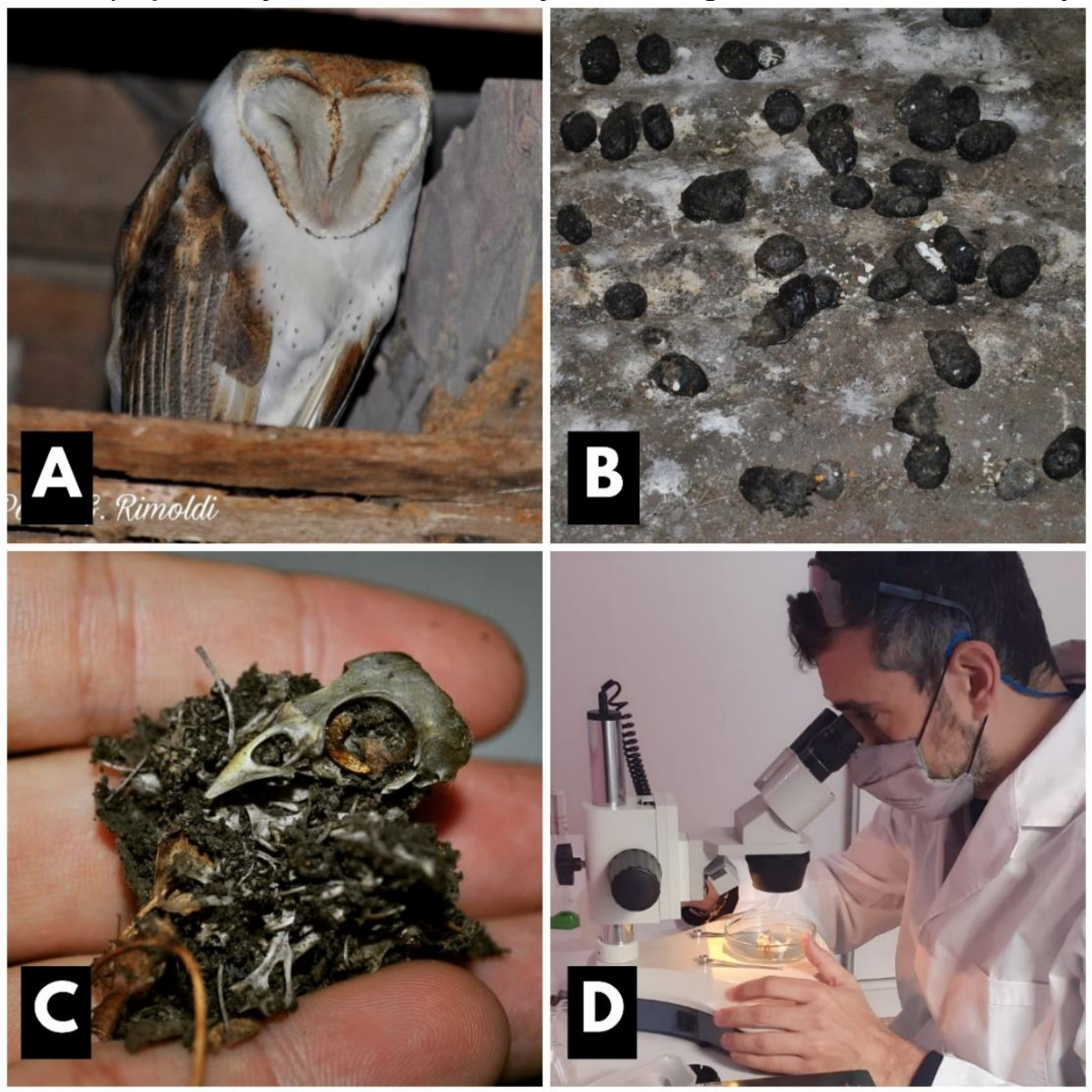


\section{RESULTS AND DISCUSSION}

The results of this study made it possible to establish the richness of birds that make up the diet of Tyto furcata in four environments in the south of the province of Santa Fe, where previous data were practically nonexistent.

A total of 2316 pellets were collected and the mean $( \pm S D)$ per environment was $579 \pm 125.5384$ prey were detected, the mean number of prey per pellet was $2.21 \pm 0.75$ (mean $\pm S D$ ). The number of pellets regurgitated by the raptor had a mean $( \pm S D)$ in the different environments of $1.6( \pm 0.34)$ with an average weight of $2.97 \mathrm{~g}( \pm$ $0.70)$.

The trophic habits of Tyto furcata in the four environments showed a diet based mainly on small mammals (97.21\%), followed by amphibians and reptiles $(2.09 \%)$ and birds $(0.70 \%)$.

Available information on the feeding habits of the barn owl in Argentina suggests that prey consumption patterns are aimed at active searches for small mammals, preying mainly on rodents (Bellocq, 1988; Polop and Busch, 2010; Fraschina, 2011; Guidobono, 2013; Massa, 2015). The results of this research are consistent with this pattern.

On the other hand, the number of individuals per pellet found in the present work was very similar to that observed in central Chile (average of 1.81; Begall, 2005), in Antioquia, Colombia (average of 2.0; Delgado and Cataño, 2004), in Valdivia, Ecuador (average of 2.2.; Moreno, 2010), in Central Oaxaca, Mexico (average of 1.88; Lavariega et al., 2016) and in agrarian ecosystems in the province of Buenos Aires, Argentina (average of 2.4; Bellocq 1988). Regarding the amount of pellets regurgitated per day the results were within the expected since it is in agreement with what was mentioned by Bellocq 1988 (average 1.7), Hercolini 2007 (average 1.4) and Massa 2015 (average 1.4) for different sites of the Pampas ecoregion. Similar to what has been mentioned so far occurs with the weight per pellet, which is within the range of what has been documented in other research related to the trophic habits of this raptor (average weight 2.17gr Bellocq, 1988; 3.8gr Gonzáles-Calderón, 2017).

Regarding the birds consumed ( $\mathrm{n}=37$ ) (see Table 1) (see Fig. 3), it can be mentioned that the family with more representatives predated was Thraupidae $(\mathrm{n}=19)$ with three genera: Sicalis, Zonotrichia and Sporophila. The average body size of the total prey was 17

centimeters (based on the approximate measurements mentioned by de la Peña, 2016). The largest being Nothura maculosa $(22.5 \mathrm{~cm})$ and an average weight of $250 \mathrm{gr}$. and the smallest represented by the genera Serpophaga, Troglodytes, Polioptila and Sporophila $(11 \mathrm{~cm})$ and an average weight of 9 gr. 
Table 1. List of birds predated by Tyto furcata in each type of environment surveyed in the Casilda District, southern Santa Fe province. References: ARNAN: Non-anthropized rural or natural environment; AP/S: Periurban/suburban environment; ARA: Anthropized rural environment; AU: Urban environment. O: Autumn; I: Winter; P: Spring; V: Summer.

\begin{tabular}{|c|c|c|c|c|c|c|c|c|c|c|c|c|c|c|c|c|}
\hline \multirow[t]{2}{*}{ SPECIES } & \multicolumn{4}{|c|}{ ARNAN } & \multicolumn{4}{|c|}{$\mathrm{AP} / \mathrm{S}$} & \multicolumn{4}{|c|}{ ARA } & \multicolumn{4}{|c|}{$\mathrm{AU}$} \\
\hline & $\mathbf{O}$ & I & $\mathbf{P}$ & $\mathbf{V}$ & $\mathbf{O}$ & $\mathbf{I}$ & $\mathbf{P}$ & $\mathbf{V}$ & $\mathbf{O}$ & I & $\mathbf{P}$ & $\mathbf{V}$ & $\mathbf{O}$ & I & $\mathbf{P}$ & $\mathbf{V}$ \\
\hline \multicolumn{17}{|l|}{ STRUTHIONIFORMES } \\
\hline \multicolumn{17}{|l|}{ Tinamidae } \\
\hline Nothura maculosa & - & - & - & - & - & - & - & - & - & - & 1 & - & - & - & - & - \\
\hline \multicolumn{17}{|l|}{ COLUMBIFORMES } \\
\hline \multicolumn{17}{|l|}{ Columbidae } \\
\hline Columbina picui & - & - & - & - & - & - & - & 2 & - & - & - & - & - & - & - & - \\
\hline Zenaida auriculata & - & - & - & - & 1 & - & - & - & - & - & - & - & - & - & 1 & 1 \\
\hline \multicolumn{17}{|l|}{ PASSERIFORMES } \\
\hline \multicolumn{17}{|l|}{ Furnariidae } \\
\hline Furnarius rufus & - & - & - & 1 & - & - & - & 1 & - & - & - & - & - & - & - & - \\
\hline \multicolumn{17}{|l|}{ Tyrannidae } \\
\hline Serpophaga sp. & - & - & 1 & - & - & - & - & - & - & - & - & - & - & - & - & - \\
\hline Tyrannus savana & - & - & - & - & - & - & 1 & - & - & - & - & - & - & - & - & - \\
\hline \multicolumn{17}{|l|}{ Troglodytidae } \\
\hline Troglodytes aedon & - & - & - & - & - & - & - & - & - & - & 1 & - & - & - & - & - \\
\hline \multicolumn{17}{|l|}{ Polioptilidae } \\
\hline Polioptila dumicola & - & - & 1 & - & - & - & - & - & - & - & - & - & - & - & - & - \\
\hline \multicolumn{17}{|l|}{ Thraupidae } \\
\hline Sicalis sp. & - & - & 2 & - & 4 & 2 & - & 3 & - & 3 & 2 & - & - & - & - & - \\
\hline Zonotrichia capensis & - & - & - & - & - & - & - & 2 & - & - & - & - & - & - & - & - \\
\hline Sporophila caerulescens & - & - & - & - & - & - & - & - & - & 1 & - & - & - & - & - & - \\
\hline \multicolumn{17}{|l|}{ Fringillidae } \\
\hline Spinus magellanicus & - & - & - & - & - & - & - & - & - & - & 1 & - & - & - & - & - \\
\hline \multicolumn{17}{|l|}{ Passeridae } \\
\hline Passer domesticus & - & - & - & - & - & - & 1 & 2 & - & - & 1 & - & - & - & - & - \\
\hline \multicolumn{17}{|l|}{ Icteridae } \\
\hline Molothrus sp. & - & - & - & - & - & - & - & 1 & - & - & - & - & - & - & - & - \\
\hline
\end{tabular}




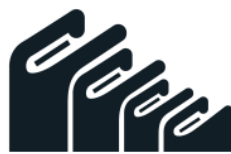

SOUTH FLORIDA JOURNAL OF ENVIRONMENTAL

Figure 3. Example of some birds predated by Tyto furcata in the different environments studied: A) Nothura maculosa, B) Zenaida auriculata, C) Tyrannus savana, D) Zonotrichia capensis, E) Sporophila caerulescens, F) Spinus magellanicus.

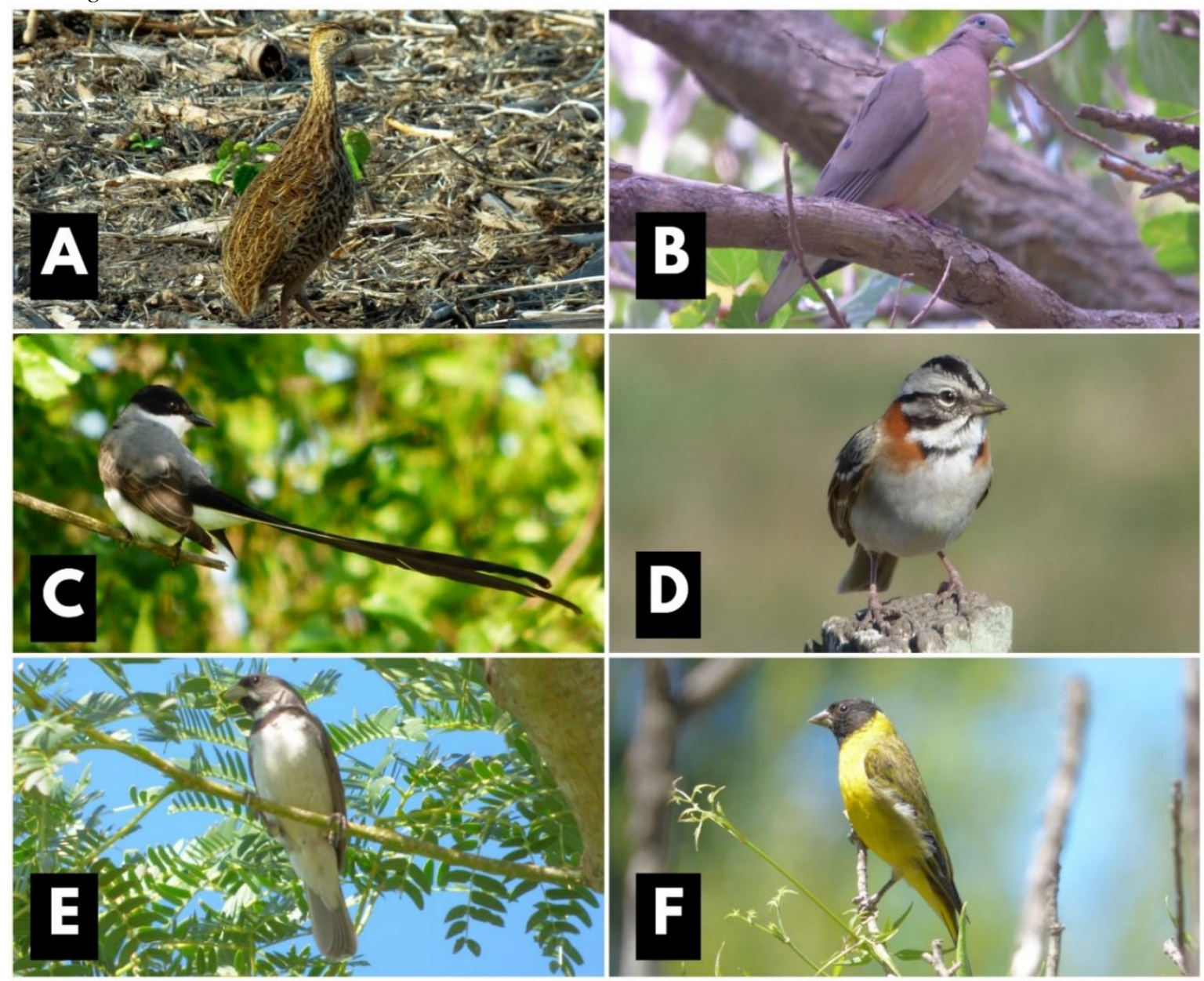

Although active bird consumption was observed in all the environments studied, three patterns can be established. 1) Bird consumption was highest in the warmer months. As with other Strigiformes, the seasonal variation in the diet of Tyto furcata in the four environments studied could be explained by the seasonal cycles of abundance of rodent prey. In this case, bird consumption tends to increase numerically during spring and summer due to the decrease in rodent populations as a result of mortality caused by climatic factors, the decrease in trophic resources and predation (Rimoldi and Curti, 2021b). 2) The highest diversity, understood as the relationship between specific richness and relative abundance, occurred in the peri-urban/suburban (PA/S) environment. Being a complex (vertical variation) and heterogeneous (horizontal variation) environment, an important diversity of birds is observed, since it contains diverse microhabitats that can be occupied by species with different requirements. A similar situation was expected to be found in the Rural Non- Anthropized or Semi-Natural (ARNAN) environment considering the characteristics of the landscape. The low number of bird species consumed in this environment may be due to the high diversity of small mammals that inhabit the site and are the main prey item of this raptor (Rimoldi and Curti 2021a). 3) Most of the species found in the samples were observed in environments 
close to the roosts. Considering that it is a species categorized as opportunistic, it can be assumed that Tyto furcata consumed those prey items that were present in more abundant concentrations and easily accessible at the time of capture within its territorial range.

On the other hand, the dominance of Zenaida auriculata stands out in urban (AU) and periurban/suburban (AP/S) environments which is in agreement with references regarding the abundance of this species in highly anthropized areas (Bucher, 2016; Gastaudo et al., 2019).

The present contribution demonstrates the importance of continuing this type of exploratory descriptive studies in order to develop actions aimed at increasing research on key, threatened and ecologically relevant species present in the area, in order to incorporate effective strategies in conservation proposals that lead to the sustainable management of resources in the region. 


\section{BIBLIOGRAPHY}

Begall, S. 2005. The relationship of foraging habitat to the diet of Barn Owls (Tyto alba) from Central Chile. Journal of Raptor, 39(1):97-101.

Bellocq, M.I. 1988. Predation of rodents by birds in agricultural ecosystems. Doctoral dissertation. Univ. Buenos Aires.

Bellocq M. I. 1990. Composition and temporal variation in the diet of Tyto alba in Pampean agrarian ecosystems, Argentina. Neotropical Wildlife 2:32-35.

Bó, M.S. Balandron, A.V. and Biondi L.M. 2007. Trophic ecology of Falconiformes and Strigiformes: time for synthesis. Hornero 22:97-115.

Bucher, E. H. 2016. The Woodpigeon. An Agricultural and urban problem. Science Today. Published in Dagrees, Volume 25, number 148.

Delgado, C.A. and E. J. F. Cataño. 2004. Diet of the Barn Owl (Tyto alba) in the lowlands of Antioquia, Colombia. Neotropical Ornithology, 15:413-45.

De la Peña, M. R. 2016a. Argentine birds: description, behavior, breeding and distribution. Rheidae to Pelecanoididae. Communications of the Provincial Museum of Natural Sciences "Florentino Ameghino" (New Series). Vol. 19 (1): 1-456.

De la Peña, M. R. 2016b. Argentine birds: description, behavior, reproduction and distribution. Ciconiidae to Heliornithidae. Comunicaciones del Museo Provincial de Ciencias Naturales "Florentino Ameghino" (New Series).Vol. 19 (2): 1-436.

De la Peña, M. R. 2016c. Argentine birds: description, behavior, breeding and distribution. Charadriidae to Trochilidae. Comunicaciones del Museo Provincial de Ciencias Naturales "Florentino Ameghino" (New Series).Vol. 20 (1): 1-627.

De la Peña, M. R. 2016d. Argentine birds: description, behavior, breeding and distribution. Trogonidae to Furnariidae. Communications of the Provincial Museum of Natural Sciences "Florentino Ameghino" (New Series). Vol. 20 (2): 1-620.

De la Peña, M. R. 2016e. Argentine birds: description, behavior, breeding and distribution. Tyrannidae to Turdidae. Communications of the Provincial Museum of Natural Sciences "Florentino Ameghino" (New Series). Vol. 21 (1): 1-633.

De la Peña, M. R. 2016f. Argentine birds: description, behavior, breeding and distribution. Mimidae to Passeridae. Communications of the Provincial Museum of Natural Sciences "Florentino Ameghino" (New Series). Vol. 21 (2): 1-564.

d'Hiriart, S.; Ortiz, P. E.; González, F. R.; Jayat, J. P. 2017. Trophic ecology of the barn owl (Tyto furcata) in the Yungas of northwestern Argentina. Ecología Austral. 027(03):364-374. https://doi.org/10.25260/EA.17.27.3.0.505. 
Dieguez, A. and Corbella, C. 1997. "Birds predated by Tyto alba - 3 - in Reserva Natural La Felipa, Ucacha, Dto. Juárez Celman, Pcia. de Córdoba". APRONA Scientific Bulletin 31: 12 14.

Fraschina J. 2011. Effects of land use changes on rodent assemblages in Pampean agroecosystems. Faculty of Exact and Natural Sciences. University of Buenos Aires.

Fulk, G.W. 1976. Owl predation and rodent martality: a case study. Mammalia, 40:423-427.

Gastaudo J.; Alesio, C.; Biasatti, N.; Marc, L.; Spiaggi, E. and P.G. Rimoldi. 2019. Study on the avifauna of two agricultural establishments with contrasting productive systems in southern Santa Fe. Notulas faunísticas - Segunda Serie, 266 (2019): 1-6, ISSN (print) 0327-0017 - ISSN (online) 1853-9564.

González Acuña, D., Ausset Salgado, M., Skewes Ramm, O., Figueroa Rojas, R. A. 2004. Seasonal variation in rodent consumption by the Barn Owl (Tyto alba) in a suburban area of Chillán, south-central Chile. Hornero 019 (02): 061-068.

González-Calderón, A. 2017. Diet of the barn owl (Tyto alba) in Ocoyoacac, State of Mexico. Huitzil, 18(2), 212-222. https://doi.org/10.28947/hrmo.2017.18.2.279

González Fischer, G., C. M. Baldi, M. Codesido, and D. Bilenca. 2012. Seasonal variations in small mammal- landscape associations in temperate agroecosystems: a case study in Buenos Aires province, central Argentina. Mammalia 76:399-406.

Guidobono J. S. 2013. Population dynamics of rodents in agroecosystems and their relationship with environmental variables. Faculty of Exact and Natural Sciences. University of Buenos Aires.

Hercolini C. 2007. Effects of urbanization on small rodent communities in the Metropolitan Area of Buenos Aires, Argentina. Bachelor's thesis. University of Buenos Aires, Buenos Aires.

Marti, C.D. 1987. Food consumption and pellet formation rates in four owl species.

Wilson Bull. 85:178-181.

Massa C. 2015. Landscape ecology: small rodent communities in the Province of Entre Ríos. Faculty of Exact and Natural Sciences. University of Buenos Aires. http://hdl.handle.net/20.500.12110/tesis_n5808_Massa

Massoia, E.; J.C. Chebez and S. Heinonen Forta-bat. 1989. Mammals and birds predated by Tyto alba tuidara in Bonpland, Candelaria Department, Misiones Province. APRO-NA, Boletín Científico, 15: 19-24.

Moreno, P.A. 2010. Mammals present in the diet of the barn owl (Tyto alba) in Valdivia, Guayas province, Ecuador. Advances in Science and Engineering, 2(3):87-90.

Morici, A. 1990. "Birds predated by Tyto alba tuidara in Desaguadero, Capital Department, Corrientes Province." APRONA Scientific Bulletin 18: 18-19.

Muñoz-Pedreros, J. Rau and J. Yañez (eds). 2004. Birds of prey of Chile. ISBN:9567279-08-X Editorial CEA, 387 pp. 
Noriega J.I, Aramburú R.M, Justo E.R and De Santis L.J.M. 1993. Birds present in pellets of Tyto alba (Strigiformes, Tytonidae) from Casa de Piedra, Argentina. Journal of Raptor Research 27:37-38.

Paiz D.; Alesio, C. and P. G. Rimoldi. 2019. Seasonal variation of micromammals consumed by Tyto furcata in the grounds of the Faculty of Veterinary Sciences (UNR). XXXII Jornadas Argentinas de Mastozoología, Puerto Madryn, Argentina. Pp. 164Pardiñas, U. F. J., and S. Cirignoli. 2002. Annotated bibliography on raptor pellet analyses in Argentina. Neotropical Ornithology 13:31-59.

Polop, J. J. and M. Busch. 2010. Biology and Ecology of small rodents in the Pampean region of Argentina: Approaches and perspectives. National University of Córdoba, 1st Edition. Pp: 325

Ramirez O, Bearez P and Arana M. 2000. Observations on the diet of the barn owl in the Quebrada de los Burros (Tacna department, Peru). Bulletin de l' Institut Français d'Études Andines 29:233240 .

Rimoldi P. G. 2020. Specific richness and relative abundance of native rodents (Rodentia: Cricetidae) preyed by Tyto furcata in the South of Santa Fe province, Argentina. Brazilian Journal of Animal and Environmental Research. ISSN 2595-573X, v.3, n. 4, p. 4123-4133, out. /dez. 2020. DOI: 10.34188/bjaerv3n4-108.

Rimoldi P. G. and M. G. Curti. 2021a. Diversity and composition of a micromammal assemblage in four environments of southern Santa Fe province, Argentina. Brazilian Journal of Animal and Environmental Research, Curitiba. ISSN 2595-573X, v.4, n.1, p. 1075-1094 Jan./Mar. DOI: 10.34188/bjaerv4n1-087

Rimoldi P. G. and M. G. Curti. 2021b. Trophic ecology of the barn owl (Tyto furcata) in four environments of southern Santa Fe province, Argentina. Bol. Mus. Hist. Nat. Parag. Vol. 25, no. 1 (Jun. 2021): 20-32.

Rimoldi P.G. 2021a. Seasonal variation in rodent consumption by the barn owl (Tyto furcata) in a relict of Espinal in southern Santa Fe, Argentina. International Journal of Zoology Studies (www.zoologyjournals.com). ISSN: 2455-7269. Volume 6, Issue 2, 2021,

Page No. 50-56

Rimoldi P.G. 2021b. Tyto Furcata's Diet Analysis in Two Natural Protected Areasin the South of Santa Fe Province, Argentina. J Archiv Zool Stud 4: 015. DOI: 10.24966/AZS- 7779/100015.

Solaro, C.; Santillán, M.A.; Costán, A.S. and M.M. Reyes. 2012. Trophic ecology of Athene cunicularia and Tyto alba in the Curru-Mahuida hill, Monte-Espinal ecotone, La Pampa, Argentina. Hornero, 27(2):177-182. 